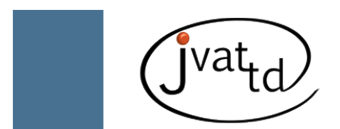

\title{
Putative new heat-stable cytotoxic and enterotoxic factors in culture supernatant of Escherichia coli isolated from drinking water
}

\author{
Ribeiro DA (1), Niemann FS (1), Gatti MSV (1), Lanna MCS (2), Tsuji T (3), Yano T (1)
}

(1) Department of Genetics, Evolution and Bioagents, Institute of Biology, State University of Campinas, UNICAMP, Campinas, São Paulo State, Brazil; (2) Laboratory of Microbiology, Department of Exact and Biological Sciences, ICEB, Federal University of Ouro Preto, UFOP, Ouro Preto, Minas Gerais State, Brazil; (3) Department of Microbiology, School of Medicine, Fujita Health University, Toyoake, Aichi, Japan.

\begin{abstract}
Enteric infections caused by the ingestion of contaminated water, especially by Escherichia coli, are important to define the virulence properties of these bacteria. Due to frequent infantile diarrhea in the city of Ouro Preto, Minas Gerais state, Brazil, the phenotypic and genotypic diarrheagenic properties of $E$. coli isolated from drinking water were studied. The culture supernatants of $39(40 \%)$ among a total of $97 \mathrm{E}$. coli isolates from drinking water were positive by suckling mouse assay and induced cytotoxic effects on Vero cells. The enterotoxic and cytotoxic activities were present in the fraction with less than $10 \mathrm{kDa}$ and were not lost when heated up to $60^{\circ} \mathrm{C}$ and $100^{\circ} \mathrm{C}$ for 30 minutes. PCR assays showed that among these 39 Vero cytotoxigenic E. coli, four (10.2\%) were positive for ST II (estB) and two (5\%) positive for aHly (hlyA). Gene amplification of SLT (stx 1, stx 2), ST I (estA), LT (eltl, eltll), EAST1 (astA), EHly (enhly) and plasmidencoded enterotoxin (pet) were not observed. This heat-stable cytotoxic enterotoxin of $E$. coli is probably a new putative diarrheagenic virulence factor, as a toxin presenting these characteristics has not yet been described.
\end{abstract}

Key words: Escherichia coli, drinking water, cytotoxin, enterotoxin.

Diarrhea caused by microorganisms remains one of the main sources of morbidity and mortality to humans, mainly in developing countries, where water treatment for consumption is inadequate or nonexistent. Acute diarrhea is mainly attributable to increased intestinal secretion, commonly as a result of infection with enterotoxin-producing microorganisms (enterotoxigenic E. coli, Vibrio cholera) or due to decreased intestinal absorption provoked byinfection with organisms that damage the intestinal epithelium (enteropathogenic $E$. coli, Shigella sp., Salmonella sp.) (1).

Among the bacteria involved in human enteric infections, Escherichia coli is one of the main enteropathogens. Despite being a mammalian commensal bacterium, E. coli is massively shed into the environment and may contaminate animal food or other resources such as vegetables and fruits, as well as underground sources of and drinking water (2). Water sources are one of the most common vehicles of transmission and a primary public health concern in developing countries, given the ingestion of inadequately treated or otherwise poor quality water that causes mainly infantile diarrhea, which provokes a high incidence of child death in these countries $(1,3)$.

Enteropathogenic E. coli provokes diarrhea by diverse mechanisms including enterotoxin/ cytotoxin production or mucosal adhesion to the small intestinal surface. Based on pathogenic mechanisms, epidemiology and clinical presentation, diarrheagenic E. coli strains can be classified into six categories: enterotoxigenic $E$. coli (ETEC), enteropathogenic E. coli (EPEC), enterohemorrhagic E. coli (EHEC), enteroinvasive 
E. coli (EIEC), enteroaggregative E. coli (EAEC) and diffuse adherent E. coli (DAEC) (4).

Various cases of $E$. coli-contaminated water have been described in several places. One of them happened in the American state of Missouri, where 243 of its habitants had diarrhea from December 1989 to January 1990. The source of contamination was the municipal drinking water supply, which was inadequately maintained (5).

The water of supplying systems for the population of Ouro Preto, state of Minas Gerais, Brazil, is captured directly from water springs, without adequate protection and exposed to domestic animals. These water springs are originated from the rocks nearby urban neighborhoods unsupplied with treated sewage system and water treatment station. Due to the frequent infantile diarrhea observed in this city, our group focused on the study of the microbiological quality of the municipal drinking water, of which $70 \%$ of the samples analyzed showed the presence of E. coli contamination (unpublished data).

The water samples were collected directly in sterile glass flasks from the taps of the population's houses. Isolation and identification of $E$. coli were carried out at the Microbiology Laboratory of the Federal University of Ouro Preto, MG, Brazil. The colonies on eosin methylene blue (EMB) agar that showed a metallic glow were afterwards confirmed to be E. coli using the EPM-MILi and simmons citrate agar (Difco, USA) media $(6,7)$.
A total of 97 E. coli isolates (one colony per water sample) was submitted to enteropathogenic virulence factor analysis. Firstly, the E. coli isolates were cultured in $10 \mathrm{~mL}$ of Luria broth (Difco Lab., USA) and shaked at $150 \mathrm{rev} \mathrm{min}^{-1}$ (New Brunswick Scientific Co, USA) for 18 hours at $37^{\circ} \mathrm{C}$. The culture supernatants were obtained by centrifugation $\left(10,000 \mathrm{~g}\right.$ for 30 minutes at $\left.4^{\circ} \mathrm{C}\right)$ and filtered through a $0.22-\mu \mathrm{m}$ filter (Millipore Corp., USA).

Cytotoxic activity of the filtered culture supernatants was assayed as reported by Konowalchuk et al. (8) in confluent monolayer of the Vero cell lines (African green monkey kidney) (ATCC, USA), cultivated in tissue culture flasks with Eagle's minimum essential medium (MEM, Nutricell, Brazil), supplemented with $10 \%(\mathrm{v} / \mathrm{v})$ fetal bovine serum. The plates then were incubated at $37^{\circ} \mathrm{C}$ in a $5 \% \mathrm{CO}_{2}$ chamber for 48 hours (Jouan, France). Cell monolayer morphology alteration was observed through an inverted microscope (Nikon, Japan) at 6, 18, 24 and 48 hours.

Among 97 E. coli isolates from water, 39 (40\%) culture supernatants caused cytopathic effects on Vero cells, after 12-hour assays, and showed a round shaped form with nuclear condensation, increased cytoplasmic vacuolization and granular cytoplamic condensations, but without evidence of cell detachment (Figure 1).

Moreover, all of the 39 Vero cytotoxigenic E. coli culture supernatants also presented enterotoxicity through the suckling mice assay described by
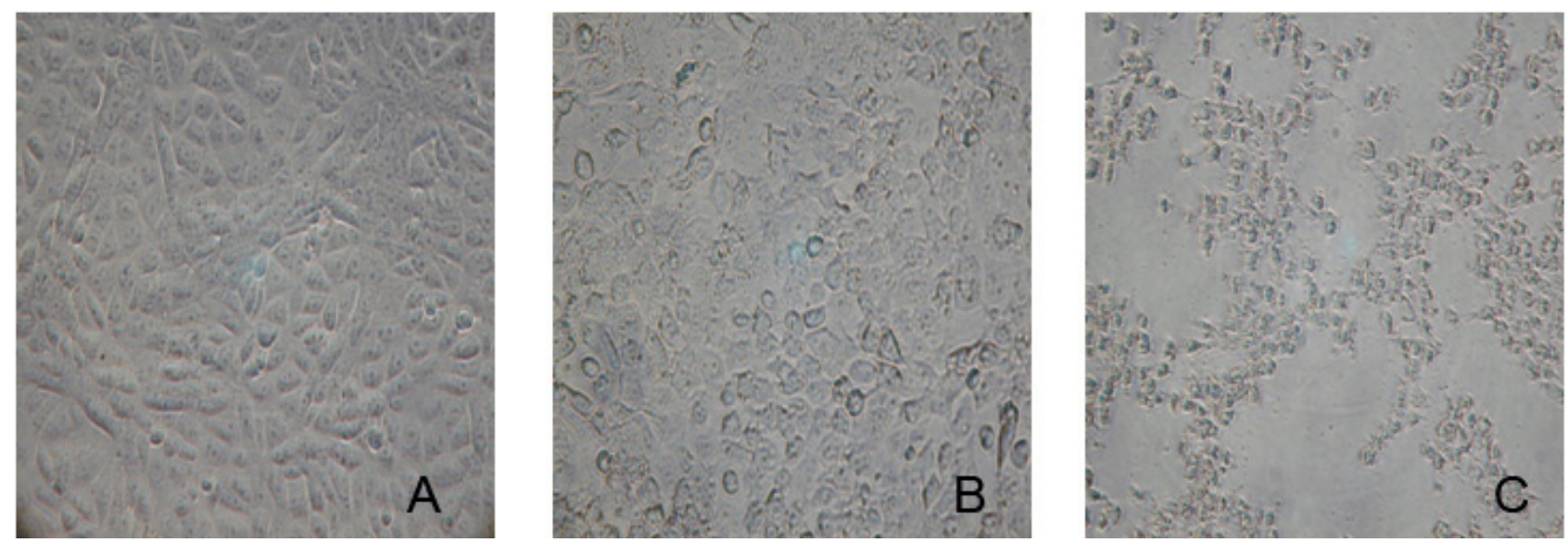

Figure 1. Vero cells under effects of ultrafiltrated (PM 10 membrane) $E$. coli culture supernatants compared to (A) control, (B) after 12 hours and (C) 24 hours. In the 12-hour culture, the cells became round shaped with nuclear condensation and increased cytoplasmic vacuolization. After 24 hours, most of the cells showed pyknotic-like nucleus and smooth cytoplasmic contents, but without evidence of cell detachment (magnification: 400x). 
Dean et al. (9), using five mice (Balb/C) for each sample, in which the ratio between the intestinal weight (IW) and the remaining body weight (BW), resulted in intestinal-fluid-accumulation values from 0.09 to 0.11 (data not shown), which are considered positive (9).

The biological activities (cytotoxic and enterotoxic) of the culture supernatants of $E$. coli were observed in fractions smaller than 10 $\mathrm{kDa}$ by ultrafiltation through PM-10 membranes (Amicon ${ }^{\circledR}$, Millipore, USA), presenting molecular weight lower than $10 \mathrm{kDa}$.

Furthermore, neither cytotoxic nor enterotoxic activities were abolished by heating up to $60^{\circ} \mathrm{C}$ and $100^{\circ} \mathrm{C}$ for 30 minutes (data not shown), which demonstrated that these biological activities are heat-stable.
The production of hemolytic activities of 39 Vero cytotoxigenic E. coli isolates from drinking water was examined on the trypticase soy agar containing $5 \%(\mathrm{v} / \mathrm{v})$ sheep blood, which showed that only two (5\%) caused a hemolytic halo around the colonies at $37^{\circ} \mathrm{C}$. The study demonstrates that the hemolytic activity is probably not associated with the cytotoxic or enterotoxic activities, which was observed through experimental analyses conducted with these strains.

Polymerase chain reaction (PCR) was performed as previously reported (10). The primers utilized, annealing temperatures and the amplified fragment sizes are shown in Table 1. The reactions were heated up to $94^{\circ} \mathrm{C}$ in an automated thermal cycler (Mastercycler ${ }^{\circ}$ Gradient, Eppendorf, USA) for two minutes,

Table 1. Primer sequences, annealing temperature and size of PCR-amplified gene

\begin{tabular}{|c|c|c|c|c|}
\hline Gene & Oligonucleotide sequence ( $5^{\prime} \rightarrow 3^{\prime}$ ) & $\begin{array}{l}\text { Predicted size of } \\
\text { amplified product } \\
\text { (bp) }\end{array}$ & $\begin{array}{l}\text { Annealing } \\
\text { temperature }\end{array}$ & Reference \\
\hline Stx 1 & $\begin{array}{l}\text { 1: AAG TTG CAG CTC TCT TTG AAT A } \\
\text { 2: TGC AAA CAA ATT ATC CCC TGA G }\end{array}$ & 364 & 53 & (11) \\
\hline Stx 2 & $\begin{array}{l}\text { 1: GGG CAG TTA TTT TGC TGT GGA } \\
\text { 2: GTA TCT GCC TGA AGC GTA A }\end{array}$ & 386 & 53 & (11) \\
\hline Elt $\mid$ & $\begin{array}{l}\text { 1: GGC GAC AGA TTA TAC CGT GC } \\
\text { 2: CCG AAT TCT GTT ATA TAT GTC }\end{array}$ & 696 & 47 & (12) \\
\hline Eltll & $\begin{array}{c}\text { 1: AGA TAT AAT GAT GGA TAT GTA TC } \\
\text { 2: TAA CCC TCG AAA TAA ATC TC }\end{array}$ & 300 & 48 & (12) \\
\hline Estl & $\begin{array}{l}\text { 1:TCC GTC AAA CAA CAT GAC GC } \\
\text { 2: ATA ACA TCC AGC ACA GGC AG }\end{array}$ & 244 & 50 & (13) \\
\hline Estll & $\begin{array}{l}\text { 1:GCC TAT GCA TCT ACA CAA TC } \\
\text { 2:TGA GAA ATG GAC AAT GTC CG }\end{array}$ & 278 & 50 & (11) \\
\hline HlyA & $\begin{array}{l}\text { 1: AAC AAG GAT AAG CAC TGT TCT } \\
\text { GGC T } \\
\text { 2: ACC ATA TAA GCG GTC ATT CCC GTC } \\
\text { A }\end{array}$ & 1177 & 63 & (14) \\
\hline Enhly & $\begin{array}{l}\text { 1: AAT GAG CCA AGC TGG TTA AGCT } \\
\text { 2: GCA TCA TCA AGC GTA CGT TCC }\end{array}$ & 534 & 50 & (15) \\
\hline AstA & $\begin{array}{l}\text { 1: CCA TCA ACA CAG TAT ATC CGA } \\
\text { 2: GGT CGC GAG TGA CGG CTT TGT }\end{array}$ & 111 & 50 & (14) \\
\hline Pet & $\begin{array}{l}\text { 1:ACT GGA AGG TGA AAA CAA CC } \\
\text { 2:GCA TGG CTG TCG GTA TAG GT }\end{array}$ & 501 & 53 & This study \\
\hline
\end{tabular}


followed by 30 cycles of denaturation $\left(94^{\circ} \mathrm{C}\right.$, one minute), annealing, and extension for two minutes (Table 1) and a final extension $\left(72^{\circ} \mathrm{C}\right.$, one minute). Approximately $8 \mu \mathrm{L}$ of each reaction mixture was submitted to electrophoresis in a $2 \%$ agarose gel and the PCR products were visualized by UV transillumination after staining with ethidium bromide.

The molecular study on gene encoding diarrheagenic-related toxins from E. coli (Table 1) was performed on 39 cytotoxic enterotoxinproducing E. coli strains. PCR showed that only two strains (51 and 53) presented genes for a-Hly (Table 2). These findings were confirmed with an in vitro hemolysis assay on blood agar plate (data not shown). Alpha-hemolysin ( $\alpha$-Hly) producing $E$. coli has been isolated with relative frequency from human diarrheic feces, but the association of the a-Hly to the enteropathogenic processes has not been confirmed yet $(16,17)$.

Among 39 cytotoxic and enterotoxic factorproducing $E$. coli strains, four strains $(25,45$, 66 and 71) contained genes for heat-stable enterotoxin type $2(\mathrm{STb})$, and the remaining $E$. coli did not contain the genes for heat-labile enterotoxins (eltI, eltII), heat-stable enterotoxins (est $A$, estB), Shiga-like toxins (stx1 and stx2), EAST1 (astA), enterohemolysin (enhly), or plasmid-encoded toxin (pet).

According to the literature, E. coli produces three recognized types of heat-stable enterotoxins: STa, STb and EAST1 (18). Among 39 cytotoxic enterotoxin-producing E. coli strains, four strains possessed the gene for $\mathrm{STb}$ (estB) (Table 2), but did

Table 2. Strains containing genes for STb and aHly among 39 cytotoxic enterotoxin-producing E. coli strains

\begin{tabular}{c|c|c}
\hline Strains & est $B$ & hlyA \\
\hline 25 & $+^{\mathrm{a}}$ & $-^{\mathrm{b}}$ \\
\hline 45 & + & - \\
\hline 51 & - & + \\
\hline 53 & - & + \\
\hline 66 & + & - \\
\hline 71 & + & - \\
\hline
\end{tabular}

+ ${ }^{\mathrm{a}}$ was amplified by PCR: $-{ }^{\mathrm{b}}$ was not amplified by PCR not contain the genes for heat-stable enterotoxin (estA) nor EAST1 (astA).

The STb is not active on cultured cells, although there is a technique that applies the uptake of the trypan blue dye by $\mathrm{CHO}$ to $\mathrm{STb}$ detection $(19,20)$. Therefore, it was observed that the cytotoxic activity present in the culture filtrated supernatants was not associated with the heat-stable enterotoxin type 2 (STb).

Recently, a new lethal subtilase cytotoxin family was described as produced by Shigatoxigenic E. coli (STEC) (21). Although the STEC is one of the diarrheagenic E. coli described groups, these toxins are different from our cytotoxic enterotoxin, which is heat-stable and do not provoke letal activity to mice (data not shown).

Therefore, based on our findings, it appears that these E. coli isolates in Brazil produce a lowmolecular-weight heat-stable enterotoxin with Vero cytotoxic activity that has not yet been described in the literature. We are now focused on the purification and molecular characterization of this toxic factor, in order to clarify the role of this enterotoxin and its mechanisms of inducing diarrhea. In conclusion, the heat-stable cytotoxic enterotoxin herein described might be a new virulence factor of diarrheagenic E. coli.

\section{ACKNOWLEDGMENTS}

We would like to thank Ana Stella Menegon Degrossoli, who provided technical assistance.

\section{COPYRIGHT}

(C) CEVAP 2011

\section{SUBMISSION STATUS}

Received: January 24, 2011.

Accepted: January 26, 2011.

Abstract published online: January 26, 2011.

Full paper published online: February 28, 2011.

\section{CONFLICTS OF INTEREST}

There is no conflict.

\section{FINANCIAL SOURCE}

The Coordination for Improvement of Higher Education Personnel (CAPES), The National Council for Scientific and Technological Development (CNPq) and The State of São Paulo Research Foundation (FAPESP) provided the financial grants. 


\section{ETHICS COMMITTEE APPROVAL}

The present study was approved by the Ethics Committee of the State University of Campinas (protocol number 748-1).

\section{CORRESPONDENCE TO}

TOMOMASA YANO, Departamento de Genética, Evolução e Bioagentes, Instituto de Biologia, UNICAMP, Cidade Universitaria "Zeferino Vaz", Campinas, SP, 13083-862, Brasil. Phone/fax: +55 193521 6254. Email: tyano@ unicamp.br.

\section{REFERENCES}

1. Kaur T, Ganguly NK. Modulation of gut physiology through enteric toxins. Mol Cell Biochem. 2003;253(1-2):15-9.

2. Kuhnert P, Boerlin P, Frey J. Target genes for virulence assessment of Escherichia coli isolates from water, food and the environment. FEMS Microbiol Lett. 2000;24(1):107-17.

3. Benicio MHD, Monteiro CA. Tendência secular da doença diarréica na infância na cidade de São Paulo (1984-1996). Rev Saúde Públ. 2000;34(Suppl 6):83-90.

4. Nataro JP, Kaper JB. Diarrheagenic Escherichia coli. Clin Microbiol Rev. 1998;11(1):142- 201.

5. Swerdlow DL, Woodruff BA, Brady RC, Griffing PM, Tippen S, Donnel Jr HD, et al. A waterborne outbreak in Missouri of Escherichia coli O157:H7 associated with bloody diarrhea and death. Ann Inter Med. 1992;117(10):812-9.

6. Toledo MR, Fontes CF, Trabulsi LR. MILi: um meio para realização dos testes de motilidade, indol e lisina descarboxilase. Rev Microbiol. 1982;13(3):230-5.

7. Toledo MRF, Fontes CF, Trabulsi LR. EPM: modificação do meio de Rugai e Araújo para realização simultânea dos testes de produção de gás a partir de glicose, $\mathrm{H}_{2} \mathrm{~S}$, urease e triptofanodesaminase. Rev Microbiol. 1982a;13(1):309-15.

8. Konowalchuk J, Speirs JI, Stavric S. Vero response to a cytotoxin of Escherichia coli. Infect Immun. 1977;18(3):775 -9.

9. Dean AG, Ching YC, Willians RG, Harden LB. Test for Escherichia coli enterotoxin using infant mice: application in the study of diarrhea in children in Honolulu. J Infect Dis. 1972; 125(4):407-11.

10. Blanco M, Blanco JE, Alonso MP, Mora A, Basalobre C, Munoa F, et al. Detection of pap, sfa and afa adhesin-encoding operons in uropathogenic Escherichia coli strains: relationship with expression of adhesions and production of toxins. Rev Microbiol. 1997;148(9):747-55.

11. Ojeniyi B, Ahrens P, Meyling A. Detection of fimbrial and toxin genes in Escherichia coli and their prevalence in piglets with diarrhea. The application of colony hybridization assay, polymerase chain reaction and phenotypic assays. Zentralbl Veterinarmed B. 1994;41(1):49-59.

12. Schultsz C, Pool GJ, van Ketel R, de Wever B, Speelman P, Dankert S. Detection of enterotoxigenic Escherichia coli in stool samples by using nonradioactively labeled oligonucleotide DNA probes and PCR. J Clin Microbiol. 1994;32(10):2393-7.

13. So M, McCarthy BJ. Nucleotide sequence of the bacterial transposon Tnl1681 encoding a heat-stable (ST) toxin and its identification in enterotoxigenic Escherichia coli strains. Proc Natl Acad Sci USA. 1980;77(7):4011-5.

14. Yamamoto S, Terai A, Yuri K, Kurozono $\mathrm{H}$, Takeda Y, Yoshida O. Detection of urovirulence factor in Escherichia coli by multiplex polymerase chain reaction. FEMS Immunol Med Microbiol. 1995;12(2):85-95.

15. Paton AW, Paton JC. Detection and characterization of shiga toxigenic Escherichia coli by using multiplex PCR assays for stx $1, \mathrm{stx} 2$, eaeA, enterohemorrhagic E. coli HlyA, rfbO111, and rfb O 159. J Clin Microbiol. 1998;36(2):598602.

16. Beutin L. The different hemolysins of Escherichia coli. Med Microbiol Immunol. 1991; 180(1):16782.

17. Cavalieri SJ, Bohach GA, Snyder IS. Escherichia coli alpha-hemolysin: characteristics and probable role in pathogenecity. Microbiol Rev. 1984;48(4):326-43.

18. Sears CL, Kaper JB. Enteric bacterial toxins: mechanisms of action and linkage to intestinal secretion. Microbiol Rev. 1996;60(1):167-215.

19. Okamoto K. Studies on structure and mechanism of action of heat-stable enterotoxin. Nippon Saikingaku Zasshi. 1997;52(3):553-66.

20. Beausoleil HE, Labrie V, Dubreuil JD. Trypan blue uptake by Chinese hamster ovary cultured epithelial cells: a cellular model to study Escherichia coli STb enterotoxin. Toxicon. 2002;40(2):185-91.

21. Paton AW, Beddoe T, Thorpe CM, Whisstock JC, Wilce MC, Rossjohn J, et al. AB5 subtilase cytotoxin inactivates the endoplasmic reticulum chaperone BiP. Nature. 2006;443(7111): 548-52. 